\title{
Relationship between Foreign Language Learning and Exam Stress with Gender: A Study on Tshik International University Preparatory School Students, Iraq
}

\author{
Bünyamin Celik ${ }^{1}$ \\ ${ }^{1}$ Department of Languages, Tshik International University, Erbil, Iraq \\ Correspondence: Bünyamin Celik, Tshik International University, Erbil, Iraq \\ Email: bunyamin.celik@ishik.edu.iq
}

Received: January 3, $2019 \quad$ Accepted: February 23, $2019 \quad$ Online Published: March 1, 2019

doi: 10.23918/ijsses.v5i3p311

\begin{abstract}
This study was conducted to draw attention to the issue of foreign language learning anxiety which negatively affects the foreign language learning process. It is based on the relationship between test anxiety and the gender of students which is one of the demographic features. 120 English language preparatory students at A1 level from Tishk International University Preparatory School, Iraq were selected to participate in the study. Also, an examination anxiety questionnaire consisting of 22 items was applied and the data were analyzed statistically. The important finding of the study is that students who learn English as a foreign language in a multicultural and multilingual environment in Erbil in Iraq, a Middle East country, clearly show that there is no significant relationship between gender and test anxiety. The only problem seemed to be insecurity, discomfort and lack of motivation caused by test anxiety.
\end{abstract}

Keywords: Gender, Foreign Language Anxiety, Exam Anxiety, Exam Stress

\section{Introduction}

Foreign language learning is a complex process. Language elements are related to many subjects such as cognition, learning behaviors, previous language experiences, personal characteristics of the learner and inter-group interaction. Also, learning a foreign language is a challenging process for many students. The vast majority of students have difficulty learning basic skills such as listening, speaking, reading and writing. Another difficulty in learning a foreign language is the psychology of the learner and the difficulties arising from the external environment. Because language is a means of communication, learners can often be afraid to use of the target language and have a feeling of alienation from a nonfamiliar environment and culture which causes different concerns in the learning process.

Spielberger (cited in Horwitz et al., 1991, p.27) describes anxiety as "undesirable emotional state manifested by tension, fear, irritability and stimulation of the nervous system." In addition, Freud described anxiety as "an emotional state that is associated with psychological stimulation which goes with nervousness and anger." Scovel (1978) proposed "facilitating and preventive" types of anxiety depending on the effects of anxiety on learning and performance. According to Ellis (1994), anxiety related to special situations is also known as a fear developed against special situations and events. 
The effect of anxiety, considered to be one of the basic emotions of human on learning, has been investigated and researched by psychologists and educational scientists in recent years. Many researchers (Aida, 1994; Horwitz, 1986; MacIntyre \& Gardner, 1991; Young, 1991) showed that anxiety has a significant effect on both general learning and foreign language learning. In particular, they have reached the results of the research showing that students have a negative effect on foreign language learning due to the anxiety of exam.

Another fear that causes students to increase their anxiety levels in their teaching process is the examinations. The stress related to the exams and the anxiety of exam is also an important problem for the students who are learning a foreign language. Exams can be particularly stressful if they affect the individual's career choice and future opportunities (Peleg-Popko 2004). While moderate level anxiety concerns have a positive impact on academic achievement, high level of anxiety has a negative effect on performance (Ekşi 1998, Musch \& Broder, 1999). In studies focusing on the underlying causes of test anxiety, students' past experiences and beliefs (Mc Donald 2001, Kavakci et al. 2010a), family attitudes (Aslan, 2005), perceptions of course load, time management skills, and student gender are reported to be seriously effective on exam anxiety (Sansgiry \& Sail 2006). The results found in studies between sex and test anxiety, one of the variables, show that female students are more anxious than male students (Daly, Felson and Trudeau, 1991; Chang, 1997; Onwuegbuzie, Bailey, \& Daley 1997). Therefore, it is seen that individuals of different sex behave differently in terms of ways of combating anxiety. In other words, depending on many reasons, female and male students tend to react differently in similar situations; female students are more vulnerable to anxiety and discomfort than male students (Berger \& Shechter, 1996).

On the basis of the studies in Iraq, studies investigating the relationship between the level of anxiety and gender of foreign language learners are quite limited. Research by Kakamad et al. (2015) focused on the relationship between language anxiety and achievement, and test anxiety was not a focus in the study, but was considered as a factor that raised language anxiety. In another study by Ala et al. (2013), the relationship between fear of negative evaluation and test anxiety was investigated. As a result, there is no study focusing on the relationship between the test anxiety and gender of individuals. This is the main basis of this study. On the other hand, English as a foreign language is widely taught as a compulsory subject in primary, secondary and tertiary education in all regions, although there are different educational approaches between regions due to the fact that Iraq is a federal structure. Considering that the second language learning period is a complex and problematic area, it is a must to identify possible problems in the field and to present suggestions. This is the second pillar of the study. When exam anxiety is an obstacle in demonstrating student performance (Jackson, 2001), it is another necessity to examine the variables that affect anxiety.

Depending on these grounds, the foreign language anxiety experienced in the foreign language learning process has been tried to be measured. It is aimed in this study to determine the relationship between the students' test anxiety and gender in the Tishk International University Preparatory School in Erbil, Iraq's largest industrial and commercial city. The answer to the following question was investigated in this study:

- Is there a relationship between the anxiety of the learners of a foreign language and their gender? 


\section{Foreign Language Learning Anxiety Factors}

Many studies have been conducted to investigate the factors related to foreign language learning anxiety especially within the universities. Gardner, Smyth and Clement (cited in Sarigul, 2000), who examined the relationship between foreign language anxiety and age, found that the anxiety of foreign language learning increased with the age of students and the smaller the age of the students, the less damaging effects of foreign language learning anxiety. Studies on anxiety related to foreign language can sometimes be categorized into general language learning and sometimes to address the four basic skills separately. In one of these studies, Littlewood (1984) stated that students were afraid to be criticized by their teachers and friends due to their pronunciation mistakes in the new language. Language learners who feel themselves in an insecure and anxious environment close themselves to foreign language learning and this situation may prevent learning if no action is taken. Baş (2014) classified the factors that cause foreign language anxiety as speaking activities, listening activities, teaching methods and techniques, fear of making mistakes, learning environment, teacher attitudes and exams.

Studies in the literature also found that foreign language learning anxiety was associated with three types of anxiety (fear of communication, anxiety of exam and fear of negative evaluation). Aydin's (2016) research findings suggest that fear of negative evaluation predicts foreign language learning anxiety. In some studies (Aydın, 2016; Aksoy, 2012; Chu, 2008), a positive relationship was found between foreign language anxiety and shyness. The fear of evaluation is that the person thinks that their environment will evaluate them negatively. Such negative thoughts lead the person to escape from the environment they are evaluated. A third type of anxiety is a kind of test anxiety, which is defined as somehow a performance anxiety due to fear of failure in academic evaluation environments. (Horwitz, Horwitz, \& Cope, 1991). In their study, Aydın and Zengin (2008) listed the proficiency levels of foreign language students, the behaviors of teachers, exam practices, difficulty level of foreign language courses, linguistic level of students and cultural differences as factors causing anxiety. Foreign language anxiety plays an important role in the literature.

In recent years, research has been accelerated in order to examine the effects of anxiety on teaching and learning processes. These studies conducted on the relationship between anxiety and gender (Aida, 1994; Batumlu \& Erden, 2007; Kitano, 2001; Marwan, 2007; Öner \& Gedikoglu, 2007; Sarigul, 2000; Sertçetin, 2006) and between anxiety and language performance (Aida, 1994; Chastain, 1975; Horwitz, 1986, 2001; Horwitz, Horwitz, \& Cope, 1986; Kleinmann, 1977; MacIntyre \& Gardner, 1989; Philips, 1992; Scovel, 1978).

In the literature, it is possible to see different studies investigating the relationship between sex and foreign language learning anxiety. However, in some of these studies, as being parallel to the findings of this study, foreign language anxiety does not show any change according to gender (Sarıül, 2000; Batumlu, 2006), while in some of them, foreign language anxiety levels differ between girls and boys (Aida, 1994; Dalkılıç, 2001). In a study that has another perspective on gender in the education process, it has been found that reading comprehension, which is the key to success in all class levels and fields and which includes a complex mental process in mother tongue and foreign language teaching, differs in favor of girls according to gender. For example, in the American National Education Development Study, reading comprehension levels of female and male students studying in the 4th grade between 1988 and 1996 were 
examined. As a result of the research, female students were found to be more successful than male students (Ruddell, 2002). In another study in which fourth grade students $(n=281)$ participated, female students were found to be more successful in reading comprehension than male students (Kudek \& Sinclair, 2001). Pomerantz, Saxon and Altermatt (2002), in their study, 466 girls and 466 male students in the 4th, 5th and 6th grade took place. In this study in which different achievements were evaluated, it was found that female students were more successful in both science, mathematics, native language and foreign language (writing, speaking, reading comprehension skills) than male students. Similar results were found in many studies in the literature (Brantmeier, 2000; Moss, 2000; Phakiti, 2003; Rothman, 2002). Therefore, one of the main objectives of the foreign language teaching lessons based on these results is that the meaning of reading and understanding of what is important in both the education process and social life of the individuals varies according to gender.

\section{Methodology}

The subject group consisted of 120 randomly selected English preparatory students studying at the Tishk International University Preparatory School in Erbil, Iraq and accepting to participate voluntarily in the research. Of the participants, 57 (47.5\%) were male and 63 (52.5\%) were female. All of the students are university preparatory students and their ages are between 17 and 19 years old. In addition, all students were graded at A1 level according to the Common European Framework of Reference for Languages (CEFR) in the English proficiency exam at the time of enrollment at the University (Council of Europe, 2011).

A questionnaire consisting of two parts was applied as descriptive data collection tool: In the first part, the variables such as age, gender and classes of the candidates were asked. In the second part, a 22 - item questionnaire which was adapted from the test anxiety questionnaire developed by Sarason (1984) was presented. The reliability coefficient of the Likert-type questionnaire was found to be Alpha $=0.85$.

In the sixth week of the 2018 - 2019 academic year, the classes were visited and questionnaires were conducted with the permission of the directorate of the Preparatory School. All data were then analyzed using SPSS software for the relationship between the participants' sexes and the test anxiety level. Firstly, the reliability coefficient for the data collected was calculated in Alpha (Cronbach's alpha) (Cho, E. 2016) model, and arithmetic mean, standard deviation and standard error values were found based on the gender variable. Standard deviation and standard error values showed that the group was homogeneous. The relationship between gender and test anxiety was calculated by calculating the Pearson Correlation coefficient.

\section{Results and Discussion}

The findings of the study are discussed in two sections: First, the distribution of the test anxiety level according to gender was presented and then the relationship between gender and exam anxiety level was examined. When the arithmetic mean values are examined, it is seen that the participants generally have anxiety about exams. It is possible to evaluate the level of anxiety according to gender in two respects. The difference in the anxiety levels of male and female students varies according to some items in the test anxiety questionnaire. In other words, when some items are considered, it is clear that female students are 
more anxious; and in some other items, male students appeared to be more anxious. Table 1 below shows the results of the distribution of test anxiety in terms of gender. The results are as follows:

- Female students more often get stuck to the idea that other students are better than themselves at the time of examination when compared to boys.

- Female students feel less uncomfortable and insecure when they learn about the exam, they think more unrelated things during the exam.

- Female students think that their fears of failing the exam are more intense than male participants.

- Female students are more emotionally affected by the exams, and often have a problem of forgetting what they know.

- Female students work less when they get a bad mark, which has a negative impact on their performance.

- Female students think that exams do not have instructive aspects.

In addition to these;

- Male students have more intense anxiety than female participants when they learn that they will be in exams and exams.

- Male students' exam concerns still continue during exam preparation and after the examination.

- Male students confuse their knowledge more as a result of test anxiety.

- Male students cannot predict their success during the exam and their assumptions are limited.

- Male students find the examinations more tedious and repulsive than girls.

- Male students feel more pressured about time limit when compared to girls, which turns into a different factor in which they feel more intense about the test.

Table 1: Distribution of test anxiety by gender:

\begin{tabular}{|l|l|c|c|c|}
\hline \multicolumn{1}{|c|}{$\mathrm{N}=120$ (Female =63, Male 57$)$} & & $\begin{array}{c}\text { Arithmetic } \\
\text { mean }\end{array}$ & $\begin{array}{c}\text { Standard } \\
\text { deviation }\end{array}$ & $\begin{array}{c}\text { Standard } \\
\text { error }\end{array}$ \\
\hline \multirow{3}{*}{ I feel anxious during the exam. } & Female & 3.4 & .0 .74 & .0 .17 \\
\cline { 2 - 5 } & Male & 3.61 & .0 .89 & .0 .1 \\
\cline { 2 - 5 } & Total & 3.57 & .0 .87 & .0 .09 \\
\hline \multirow{3}{*}{$\begin{array}{l}\text { During the exam, I have the idea that } \\
\text { the other students are better than me. }\end{array}$} & Female & 2.9 & .0 .78 & .0 .16 \\
\cline { 2 - 5 } & Male & 2.84 & .0 .99 & .0 .1 \\
\cline { 2 - 5 } & Total & 2.85 & .0 .89 & .0 .09 \\
\hline \multirow{2}{*}{$\begin{array}{l}\text { I feel insecure and not comfortable } \\
\text { when I am informed that we will have } \\
\text { exam. }\end{array}$} & Female & 2.8 & .0 .93 & .0 .22 \\
\cline { 2 - 5 } & Male & 3.47 & .0 .87 & .0 .1 \\
\cline { 2 - 5 } & Total & 3.35 & .0 .91 & .0 .09 \\
\hline $\begin{array}{l}\text { During the exam, I get stuck to the } \\
\text { ideas that are irrelevent to the exam. }\end{array}$ & Female & 2.7 & .0 .61 & .0 .14 \\
\cline { 2 - 5 } & Male & 2.31 & .0 .91 & .0 .1 \\
\hline
\end{tabular}




\begin{tabular}{|c|c|c|c|c|}
\hline & Total & 2.38 & .0 .88 & .0 .09 \\
\hline \multirow{3}{*}{$\begin{array}{l}\text { I really feel nervous when I learn that } \\
\text { we will have an exam. }\end{array}$} & Female & 3.25 & .0 .76 & .0 .18 \\
\hline & Male & 3.43 & .0 .95 & .0 .11 \\
\hline & Total & 3.4 & .0 .92 & .0 .09 \\
\hline \multirow{3}{*}{$\begin{array}{l}\text { During the exam, I am obsessed with } \\
\text { the idea that I will fail. }\end{array}$} & Female & 2.75 & .0 .82 & .0 .19 \\
\hline & Male & 2.71 & .0 .79 & .0 .09 \\
\hline & Total & 2.71 & .0 .79 & .0 .08 \\
\hline \multirow{3}{*}{ Anxiety continues after the exam. } & Female & 2.9 & .1 .16 & .0 .27 \\
\hline & Male & 3.2 & .0 .76 & .0 .09 \\
\hline & Total & 3.08 & .0 .85 & .0 .09 \\
\hline \multirow{3}{*}{$\begin{array}{l}\text { I still do not feel secure even though I } \\
\text { get a good mark. }\end{array}$} & Female & 1.98 & .0 .92 & .0 .21 \\
\hline & Male & 2.21 & .1 .1 & .0 .12 \\
\hline & Total & 2.1 & .1 .09 & .0 .11 \\
\hline \multirow{3}{*}{$\begin{array}{l}\text { After the exam, I think that I could do } \\
\text { better. }\end{array}$} & Female & 3.25 & .0 .82 & .0 .19 \\
\hline & Male & 3.51 & .0 .87 & .0 .09 \\
\hline & Total & 3.47 & .0 .87 & .0 .09 \\
\hline \multirow{3}{*}{$\begin{array}{l}\text { My feelings affect me negatively } \\
\text { during the exam. }\end{array}$} & Female & 3.45 & .1 .15 & .0 .26 \\
\hline & Male & 3.39 & .1 .1 & .0 .11 \\
\hline & Total & 3.4 & .1 .09 & .0 .11 \\
\hline \multirow{3}{*}{ I forget what I know during the exam. } & Female & 3.1 & .0 .87 & .0 .2 \\
\hline & Male & 2.99 & .0 .74 & .0 .09 \\
\hline & Total & 2.98 & .0 .76 & .0 .08 \\
\hline \multirow{3}{*}{ I feel anxious while studying for exam. } & Female & 2.99 & .0 .92 & .0 .21 \\
\hline & Male & 3.16 & .0 .84 & .0 .1 \\
\hline & Total & 3.14 & .0 .85 & .0 .09 \\
\hline \multirow{2}{*}{$\begin{array}{l}\text { The more I study the more I confuse } \\
\text { my knowledge. }\end{array}$} & Female & 2.5 & .1 .06 & .0 .24 \\
\hline & Male & 2.81 & .1 .05 & .0 .12 \\
\hline
\end{tabular}




\begin{tabular}{|c|c|c|c|c|}
\hline & Total & 2.76 & .1 .06 & .0 .11 \\
\hline \multirow{3}{*}{$\begin{array}{l}\text { I cannot predict if I will be successful } \\
\text { or not during the exam. }\end{array}$} & Female & 2.96 & .0 .89 & .0 .21 \\
\hline & Male & 2.99 & .0 .94 & .0 .11 \\
\hline & Total & 2.98 & .0 .93 & .0 .1 \\
\hline \multirow{3}{*}{ I am bored with exams. } & Female & 3.2 & .1 .05 & .0 .24 \\
\hline & Male & 3.4 & .1 .02 & .0 .12 \\
\hline & Total & 3.36 & .1 .02 & .0 .11 \\
\hline \multirow{3}{*}{$\begin{array}{l}\text { I am afraid of not being able to catch } \\
\text { up with time during the exam. }\end{array}$} & Female & 3.65 & .0 .99 & .0 .23 \\
\hline & Male & 3.76 & .1 .08 & .0 .12 \\
\hline & Total & 3.74 & .1 .1 & 0.11 \\
\hline \multirow{3}{*}{ I study less after I get low marks. } & Female & 2.9 & .1 .26 & .0 .29 \\
\hline & Male & 1.87 & .1 .02 & .0 .11 \\
\hline & Total & 1.96 & .1 .15 & .0 .12 \\
\hline \multirow{3}{*}{$\begin{array}{l}\text { I would learn more if there were not } \\
\text { exams. }\end{array}$} & Female & 2.9 & .1 .07 & .0 .25 \\
\hline & Male & 2.84 & .1 .22 & .0 .14 \\
\hline & Total & 2.85 & .1 .19 & .0 .15 \\
\hline \multirow{3}{*}{$\begin{array}{l}\text { Exams affect my performance } \\
\text { negatively. }\end{array}$} & Female & 2.9 & .1 .16 & .0 .27 \\
\hline & Male & 2.74 & .1 .06 & .0 .12 \\
\hline & Total & 2.77 & .1 .07 & .0 .11 \\
\hline \multirow{3}{*}{$\begin{array}{l}\text { I am afraid of exams even if I get } \\
\text { prepared well. }\end{array}$} & Female & 2.45 & .1 .15 & .0 .26 \\
\hline & Male & 3.15 & .1 .23 & .0 .14 \\
\hline & Total & 2.93 & .1 .24 & .0 .13 \\
\hline \multirow{3}{*}{$\begin{array}{l}\text { I am afraid of exams when I do not get } \\
\text { prepared well. }\end{array}$} & Female & 3.8 & .1 .18 & .0 .27 \\
\hline & Male & 4.3 & .1 .04 & .0 .12 \\
\hline & Total & 4.21 & .1 .08 & .0 .11 \\
\hline \multirow{3}{*}{ I feel confused before the exam. } & Female & 3.3 & .0 .79 & .0 .17 \\
\hline & Male & 3.49 & .1 .08 & .0 .2 \\
\hline & Total & 3.46 & .0 .99 & .0 .1 \\
\hline
\end{tabular}


Table 2 below shows the results of the "Distribution of exam anxiety in terms of genders":

- The Pearson coefficient and the level of significance indicating the relationship between sex and test anxiety indicate a statistically significant relationship between only three of the 22 items presented.

- Male students feel more insecure and uncomfortable than female students when they learn about the exam ( $\mathrm{p}<0.005(0.002))$.

- In addition, while there was no negative effect on male students' willingness to study in low grades, female students were negatively affected ( $\mathrm{p}<.005)$.

- Female students' anxiety diminished when they were preparing for the exams, while male students felt anxious in the same situation $(\mathrm{p}<.002)$.

Table 2. Relationship between sex and test anxiety

\begin{tabular}{|l|l|c|}
\hline Dependent Variables & \multicolumn{1}{|c|}{$\mathrm{N}=120$} & Gender \\
\hline \multirow{2}{*}{$\begin{array}{l}\text { I feel insecure and uncomfortable when I } \\
\text { learn that thre is an exam. }\end{array}$} & Pearson Coefficient & $.28^{* *}$ \\
\cline { 2 - 3 } & Significance Level & .002 \\
\hline \multirow{2}{*}{\begin{tabular}{l} 
When I get low mark, I study less. \\
\cline { 2 - 3 } $\begin{array}{l}\text { I am afraid of exams although I get prepared } \\
\text { well. }\end{array}$
\end{tabular}} & Pearson Coefficient & $-.39^{* *}$ \\
\cline { 2 - 3 } & Pearson Coefficient & .00 \\
\cline { 2 - 3 } & Significance Level & $.220^{*}$ \\
\hline
\end{tabular}

** Correlation is significant at 0.01 level.

* Correlation is significant at 0.05 level.

\section{Conclusions and Recommendations}

In this study, the reasons causing anxiety in the process of foreign language learning and negatively affecting the learning process of foreign language has been pointed out. In addition, research results were obtained on the relationship between sex, one of the demographic characteristics, and the test anxiety of the preparatory school students learning foreign languages. First of all, students who learn a second foreign language, especially English, usually have different concerns in their language learning process. The first concern of these is exam anxiety which affects the academic success of the students.

Considering the gender issue, there are differences in the level of examination anxiety among girls and boys in various situations. According to this, female students feel that other students are better than themselves, they feel more insecure and uncomfortable before the exam. In addition, girls are more anxious than males in terms of fears of failure. Male students are more anxious than girls before, during and after the exam. Moreover, male students have more intense anxiety than girls about confusing what they know as a result of exam anxiety, not being able to predict if they will be successful and timing pressure.

Another result of the study was that there was a significant relationship between gender and only three of the 22 items presented a meaningful relationship with gender. Accordingly, there is a significant relationship between gender and:

- Learning that test will take place,

- Less work in case of low note, 
- worrying about the exams

Based on this meaningful relationship, when the male students learned that they would have an exam, they felt more insecure and uncomfortable than female students. However, in case of failure, it was observed that girls were affected more negatively than boys. It is possible to say that male students are more anxious even if they are ready for the exam. The related literature shows that female students are more anxious than male students (Daly, Kreiser, \& Rogharr, 1994; Chang, 1997; Onwuegbuzie, Bailey \& Daley, 1997). However, the results obtained in this study reveal two different results. According to this, anxiety is experienced more intensely in female students and in some cases in male students. Based on the level of significance, gender appears to have a meaningful relationship with only three of the 22 items in the test anxiety survey. Thus, there is no significant relationship between gender and test anxiety in terms of 19 items. Finally, in Berger and Shechter's (1996) study, the finding that female students are more vulnerable to anxiety and discomfort than male students does not coincide with the finding in this study that underlines that males are more insecure and disturbed than females.

Depending on the results of the study, some suggestions can be presented: First, before examining the relationship between test anxiety and gender, it is generally necessary to analyze and solve the factors that cause anxiety and the consequences that result from the fact that the students are concerned about the test. In this context, the first way to cope with foreign language learning concerns is to determine in what situation anxiety emerges, before the efforts to reduce it (Sellers, 1998). Teachers, testers and practitioners should consider the following recommendations:

- Feeling of distrust and discomfort appeared more intensely in boys than girls

- Male participants are more anxious in case they are prepared for exams

- Reduction of motivation takes place as a result of anxiety in girls

On the other hand, the low level of anxiety in general may have made students reluctant to perform. In addition, many studies have shown that anxiety affects the learning negatively. However, on the contrary, lack of or no anxiety also affects learning negatively and reduces motivation. Scovel (1994) stated that language learning anxiety is a psychological fiction and this situation is mostly due to the students' own intrinsic motivating factors. In this context, reasonable anxiety can motivate the student and increase the amount of gain. Not only the ability of students to use foreign language as a tool that they can implement in real life but also allowing them to communicate with people whose mother tongue or second foreign language is English will increase their interest in the target language. This can contribute to their learning by providing them with a reasonable level of anxiety.

\subsection{Limitations of the Research}

It is important to note that this study is limited to a total of 120 University Preparatory School students, including 63 girls and 57 boys at A1 level; therefore, the findings of this study cannot be generalized to all foreign language students. However, this study can be reproduced with a large number of learners in different EFL contexts from different age groups and backgrounds for a detailed analysis. Second, since the focus of the study was on the relationship between sex and test anxiety, participatory variables such as age, success status were manipulated, and past experience effects were not considered as a variable in foreign language backgrounds of candidates. Finally, it is recommended that future studies should focus 
on other participatory variables, the causes of anxiety and the consequences of anxiety, and, in addition, special attention should be paid to students with high levels of anxiety.

\section{References}

Aida, Y. (1994). Examination of Horwitz, Horwitz, and Cope's construct of foreign language anxiety: The case of students of Japanese. Modern Language Journal, 78, 155-168.

Aksoy, M. (2012). Yabancı dil öğreniminde kaygı, utangaçlık, strateji ve akademik başarı arasındaki ilişki. Unpublished Doctoral Dissertation. Ankara University, Institute of Social Sciences.

Ala, H., Oda, A., Ali, H., Khammat, M. (2013). Investigating the Factors that Cause Language Anxiety in Iraqi EFL Learners. Journal of Basra Researches/Humanities, 38, 25-53.

Aslan, S.A. (2005). Ergenlerde ana-baba tutumu, sınav kaygısı, ders çalışma becerilerinin lise giriş sınavını yordama düzeyleri. Yayınlanmamış yüksek lisans tezi. Mersin Üniversitesi Sosyal Bilimler Enstitüsü.

Aydın, S., \& Zengin, B. (2008). Anxiety in foreign language learning: A review of literature. The Journal of Language and Linguistic Studies, 4 (1), 81 - 94.

Aydın, Y. (2016). Lise ögrencilerinin yabancı dil kaygısının farklı değişkenler açısından incelenmesi. Yayımlanmamış Yüksek Lisans Tezi, Ahi Evran Üniversitesi Sosyal Bilimler Enstitüsü, Kırşehir.

Baş, G. (2014). Lise öğrencilerinde yabancı dil öğrenme kaygısı: Nitel bir araştırma. Pamukkale Üniversitesi Eğitim Fakültesi Dergisi, 36, 101-119.

Batumlu, D. Z., \& Erden, M. (2007). The relationship between foreign language anxiety and English achievement of Y1ld1z Technical University School of Foreign Languages preparatory students. Journal of Theory and Practice in Education, 3 (1), 24-38.

Batumlu, Z.D.U., (2006). YTÜ yabancı diller yüksek okulu hazırlı ögrencilerinin yabancı dil kaygılarının ingilizce başarılarına etkisi. Yayımlanmamış Yüksek Lisans Tezi, Yıldız Teknik Üniversitesi, Sosyal Bilimler Enstitüsü, İstanbul.

Berger, R., \& Shechter, Y. (1996), Guidelines for choosing an "intervention package" for working with adolescent girls in distress. Adolescence, 31 (123), 709-719.

Brantmeier, C. A. (2000). The relationship between readers' gender, passage content, comprehension and strategy use in reading Spanish as a second language. Doctoral Dissertation. Indiana University.

Chang, J. I. (1997). Contexts of adolescent worries: Impacts of ethnicity, gender, family structure, and socioeconomic status. Paper presented at the annual meeting of NCFR Fatherhood and Motherhood in a Diverse and Changing World, Arlington, VA.

Chastain, K. (1975). Affective and ability factors in second language acquisition. Language Learning, $25,153-161$.

Cho, E. (2016). Making reliability reliable: A systematic approach to reliability coefficients. Organizational Research Methods, 19(4), 651-682.

Chu, H. N. R. (2008). Shyness and EFL learning in taiwan: a study of shy and non-shy college students' use of strategies, foreign language anxiety, motivation, and willingness to communicate. ProQuest. https://books.google.com.tr/books

Council of Europe (2011). Common European framework of reference for languages: Learning, teaching. Assessment. Council of Europe.

Dalk1lıç, N. (2001). An investigation into the role of anxiety in second language learning. Retrieved from http://www.sosyalbilimler.cukurovaom/p/articles/mi_mOFCR/is_4

Daly, J. (1991). Understanding communication apprehension: An introduction for language educators. In E. K. Horwitz \& D. J. Young (Eds.), Language anxiety: From theory and research to classroom implications (pp. 3-13). Englewood Cliffs, NJ: Prentice-Hall. 
Daly, J. A., Kreiser, P. O., \& Rogharr, L. A. (1994), Question-asking comfort: Explorations of the demography of communication in the eighth-grade classroom. Communication Education, 43, 27-41.

Ellis, R. (1994). The study of second language acquisition. Oxford: Oxford University Press.

Felson, R. B., \& Trudeau, L. (1991). Gender differences in mathematics performance. Social Psychology Quarterly, 54, 113-126.

Horwitz, E.K. (2001). Language anxiety and achievement. Annual Review of Applied Linguistics, 21, 112-126.

Horwitz, E.K., Horwitz, M.B., \& Cope A.J. (1986). Foreign language classroom anxiety. Modern Language Journal, 70, 125-132.

Horwitz, E.K., Horwitz, M.B., \& Cope, J. A. (1991). Foreign language classroom anxiety. In E. K. Horwitz \& D. J. Young (Eds.), Language anxiety: From theory and research to classroom implications (pp. 27-36). New Jersey: Englewood Cliffs.

Jackson, P. (2001), Test taking doesn't have to lead to test anxiety: [Community Edition]. http://proquest.umi.com/pqdweb?index=61\&did

Kakamad, K., \& Faqe, C. (2015). English language Learning Anxiety Among Foreign Language learners in Kurdistan Region of Iraq: Soran University as an Example. International Journal of Construction Education and Research, 3, 485-494.

Kavakci, Ö., Kuğu, N., \& Semiz, M. (2010b) Üniversite öğrencileri arasında Dikkat Eksikliği Hiperaktivite bozukluğu ve eşlik eden bozukluklar. 46. Ulusal psikiyatri Kongresi, İzmir.

Kitano, K. (2001). Anxiety in the college Japanese language classroom. The Modern Language Journal, 85 (4), 517-566.

Kleinmann, H. H. (1977). Avoidance behavior in adult second language acquisition. Language Learning, 27 (1), 93-107.

Kudek, A. L., \& Sinclair, R. J. (2001). Predicting reading and mathematics achievement in fourth-grade children from kindergarten readiness scores. Journal of Education Psychology, 93, 3, 451-455.

Littlewood, W. (1984). Foreign and second language learning; Language acquisition research and its implications for the classroom. Cambridge: CUP, pp.58-59.

MacIntyre, P. D., \& Gardner, R.C. (1991). Methods and results in the study of anxiety and language learning: A review of the literature. Language Learning, 41, 85-117.

Marwan, A. (2007). Investigating students' foreign language anxiety. Malaysian Journal of ELT Research, 3, 37-55.

Mc Donald, A.S. (2001). The prevalence and effects of test anxiety in school children. Educ Psychol, 21, 89-98.

Moss, G. (2000). Raising boys' attainment in reading some principles for intervention, reading. Published by Blackwell publishers.

Musch, J., \& Broder, A. (1999). Test Anxiety versus Academic Skills: A comparison of two alternative models for predicting performance in a statistics exam. Br J Educ Psychol, 69, 105-116.

Onwuegbuzie, A. J., Bailey, P., \& Daley, C. E. (1997). Foreign language anxiety among college students. Paper presented at the annual meeting of the Mid-South Educational Research Association, Memphis, TN.

Öner, G., \& Gedikoğlu, T. (2007). Foreign language anxiety affecting learning English of secondary school students in Gaziantep. Gaziantep Üniversitesi Sosyal Bilimler Dergisi 6 (2), 67-78.

Peleg-Popko, O. (2004). Differentiation and test anxiety in adolescents. J Adolesc, 27, 645-662.

Phakiti, A. (2003). A closer at gender and strategy use in L2 reading. Language Learning. 53, 4, 649703.

Philips, E. M. (1992). The effects of language anxiety on students' oral test performance and attitudes.

The Modern Language Journal, 76, 14-26. 
Pomerantz, E. M., Altermatt, E. R., \& Saxon, L. J. (2002). Making the grade but feeling distressed: Gender differences in academic performance and internal distress. Journal of Education Psychology, 94, 2, 396-404.

Rothman, S. (2002). Achievement in literacy and numeracy by Australian 14 year-olds, 1975-1998" LSAY Research Reports. Longitudinal surveys of Australian youth research report; n.29 http://research.acer.edu.au/lsay_research/33

Ruddell, R. B. (2002). Becoming an effective literacy teacher. Teaching children to read and write: Becoming an effective literacy teacher. London: Allyn \& Bacon.

Sansgiry, S.S., \& Sail, K. (2006). Effect of Students' Perceptions of Course Load on Test Anxiety. Am J Pharm Educ, 15,26.

Sarason, I. G. (1984). Stress, anxiety, and cognitive interference: Reactions to tests. Journal of Personality and Social Psychology, 46, 929-938.

Sarıgü, H. (2000). Trait anxiety or foreign language anxiety and their effects on learners' foreign language proficiency and achievement. (Unpublished master's thesis). Boğaziçi University, İstanbul, Turkey.

Scovel, T. (1978). The effect of anxiety on language learning: A review of the anxiety research. Language Learning, 28, 129-142.

Scovel, T. (1994). The role of culture in second language pedagogy. System, 22 (2), 205-219.

Sellers, V. D. (1998). The relationship between anxiety and reading in spanish as a foreign language. Unpublished Doctoral Dissertation. The Pennsylvania State University. USA.

Sertçetin, A. (2006). Classroom foreign language anxiety among Turkish primary school students. (Unpublished master's thesis). Uludağ University, Bursa, Turkey.

Young, D. J. (1991). Creating a low-anxiety classroom environment: What does the anxiety research suggest?. Modern Language Journal, 75, 426-439. http://dx.doi.org/10.2307/329492 